\title{
LOOKING AT MONUMENTAL STRUCTURES FROM THE VIEWPOINT OF HISTORICAL HERITAGE AND TOURISM: THE TOKAT CASE
}

\author{
Barış Ergen ${ }^{1}$ \\ Mustafa Çelik \\ Zeynep Ergen \\ Kemal Demir
}

\begin{abstract}
Monumental buildings in a historical environment are of significant value due to their centralized locations, massive scale, and striking features. Monumental buildings also play an important role in the introduction of the city in question. This study examines the tourismoriented viewpoints of the locals in Tokat on monumental buildings as cultural heritage samples. It aims to reveal both the interest of the city-dwellers in tourism, and their positive and negative views on it. The study was based on a face-to-face survey with a total of 200 people conducted in Tokat city center during the months of April and May 2016. An incidental method was used to select the survey participants. The survey was in two parts. The first included questions used to elicit the viewpoints of the locals in Tokat on tourism and tourists. The second part of the survey contained questions about the tourism-directed usage of the monumental buildings in the city, and whether these monumental buildings corresponded with tourism in terms of portraying the city image. As a result, it is observed that Tokat is an important tourist attraction with its historical texture; the locals in the city recognize the significance of tourism and they treat tourists in a hospitable manner. The historical texture and a city's history are among the most important issues in cultural tourism. Additionally, the monumental buildings are the most significant elements as they reflect the architectural features of the relevant periods.
\end{abstract}

Key words: Cultural tourism, historical heritage, monuments, Tokat

\section{CULTURE AND TOURISM}

"Attraction is an important factor in tourism, and it is largely dependent on geographic information (Gunn 1988). Various types of tourism and touristic activities emerge based on the sources of attraction" (Emekli 2006). One of the most important factors in attracting tourists is cultural tourism. While the term 'culture' has "no commonly accepted, universal definition" (Bujdosó et al. 2015), in the case of defining culture as an attraction, there are three main types: (Bujdosó et al. 2015; Mathieson and Wall 1982, DávidJancsik and Rátz 2007) inert culture (e.g. buildings, architectural styles, artistic creations, personal goods); 2) everyday culture (e.g. leisure activities, lifestyle, gastronomy); and 3) enacted culture (e.g. festivals, carnivals, traditional events) (Bujdosó et al. 2015). This study emphasises the first of these types of culture - inert

\footnotetext{
${ }^{1}$ Associate Professor, Bozok University Engineering and Architecture Faculty, Department of City and Regional Planning, Yozgat, Turkey. e-mail: ergenbaris@gmail.com
} 
culture - in the assessment of monumental buildings that serve as sources of city image, are local attractions and arouse the interest of people.

\section{HERITAGE, MONUMENTS AND TOURISM}

Kaufman and Weaver(2006)defined heritage tourism as "the experience people seek to have at a historic site (Ung and Vong2010)." Cultural heritage tourism is one vehicle through which localities can harness local culture and traditions to engage in and shape their developmental direction within broader global processes (Dredge 2004). Heritage tourism is currently one of the most notable and widespread types of tourism in terms of visitors and attractions, appealing to hundreds of millions of people every year (Nguyen and Cheung 2014; Timothy 2011).

Historical towns, cultural heritage, and historic sites and buildings are important elements of cultural tourism, and monumental buildings in historic sites in particular are regarded as one of the main reasons for tourist travel. Monuments have always been useful promotional tools for cities, employed both in traditional advertising literature and as a more subtle form of place marketing (Smith 2007). According to Verschaffel: "Monuments stand out by their central and eye-catching position, by their size, by their being placed on a pedestal, or by their massive and solid appearance" (Smith 2007). This study examines the viewpoints of the locals in Tokat Province on the monumental buildings that are an important part of local cultural tourism.

\section{METHODOLOGY}

This study examines the tourism-oriented viewpoints of the locals in Tokat on the monumental buildings as cultural heritage samples. Thus, it aims to reveal both the interest of the city-dwellers in tourism, and their positive and negative views on it. The methodology of the study was based on a face-to-face survey conducted with 200 people in Tokat city center during the months of April and May 2016. An incidental method was used to select the survey participants. The survey was in two parts. The first one included the questions used to elicit the viewpoints of the locals in Tokat on tourism and tourists. The second part of the survey contained questions about the tourism-directed usage of the monumental buildings in the city, and whether these monumental buildings corresponded with tourism in terms of the city's image.

Tokat has hosted many civilizations, such as Hittites, Persians, Romans, Seljuks, Mongols, and the Ottoman Empire. Therefore, it is possible to see many monumental buildings in Tokat Province. Tokat was selected as the sample area in this study due to its historical texture. Tokat is located in the region of Central Black Sea. The location of Tokat in Turkey and of the region where the fieldwork was conducted is shown in Figure 1. The blue area seen in the lower right corner in Figure 1 constitutes the urban urban conservation site of Tokat. The red zones in the blue areas show the city blocks where the monumental buildings selected as samples are located in the historical 
texture. The black areas indicated within the urban conservation site show the registered monumental buildings. Of these monumental buildings, 13 were selected as samples and used for the survey. Only (H1dırl1kKöprüsü-Bridge) one of these 13 monumental buildings is located outside of the urban conservation site. The photos of these monumental buildings are shown in Figure 1.

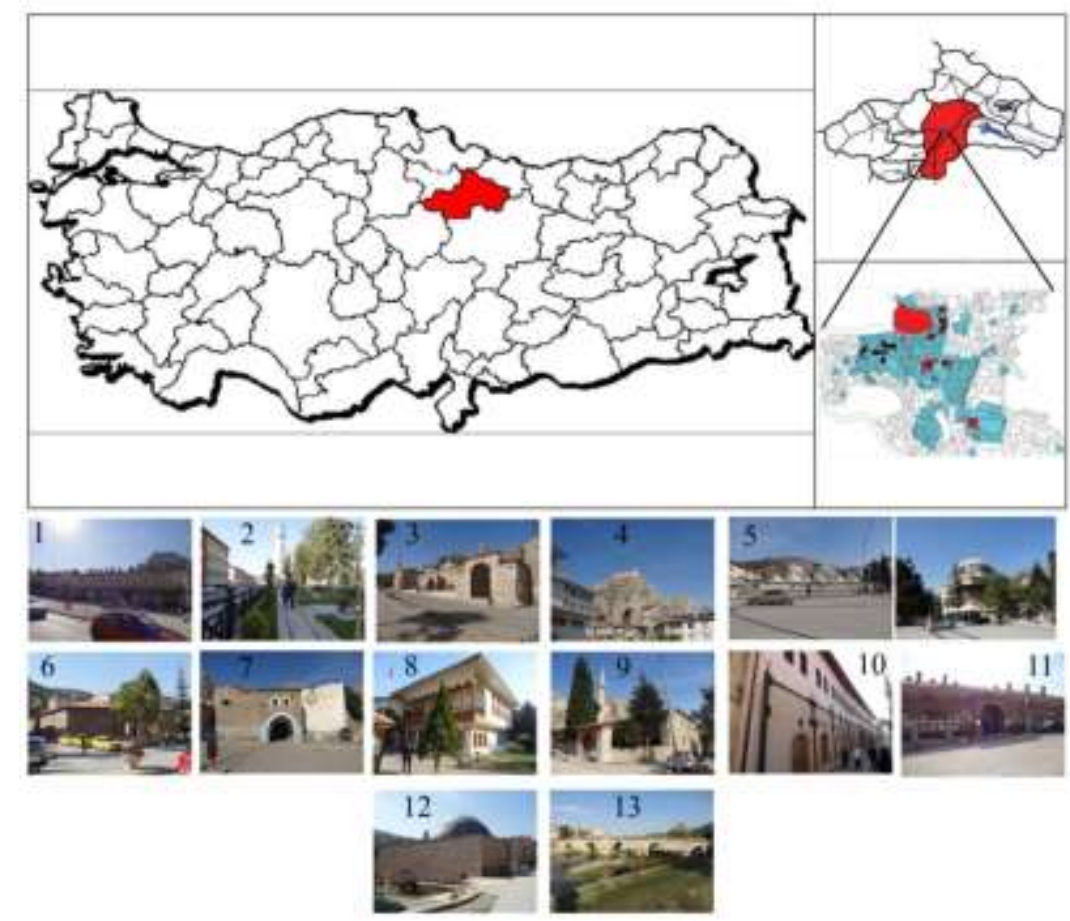

Fig. 1. The location of Tokat Province and monumental buildings.

The survey questions for the locals to determine the effects of monumental buildings in Tokat on the tourism potential of the region and the image of the city were: 1 - Do you think that Tokat is a tourist city? 2- Do you think that the historical buildings in Tokat are used adequately for tourism? 3- Is this historical texture a problem for Tokat, or an advantage? 4- Is your point of view about tourists who come to Tokat positive? 5- What is the first historical building that comes into your mind when you hear something about Tokat?

\section{RESULTS}

The questions above-mentioned in the methodology section and answers given to them are shown in Table 1. Theanalysis of Table 1 shows the following results: Of the 200 participants, 132 regarded Tokat as a tourist attraction, 195 had a positive approach to tourists, and 191 considered the historical texture of Tokat to be an advantage for it. In the second part of the survey, the participants assessed the touristic usability of the 
historical buildings, and 115 of them stated that the historical buildings in Tokat were used in tourism. It is observed in Table 1 that the locals living in Tokat have a positive look on tourism, and they regard the historical texture as an important advantage and potential. The fact that the locals think that Tokat is a tourist city indicates that the importance of tourism has been recognized by the locals.

Table 1. Tourism-oriented viewpoints on the historical texture in Tokat

\begin{tabular}{|l|l|l|l|l|}
\hline & Yes & $\begin{array}{l}\text { Percentage } \\
(\%)\end{array}$ & No & $\begin{array}{l}\text { Percentage } \\
(\%)\end{array}$ \\
\hline Is Tokat a tourist city? & 132 & $\% 66$ & 68 & $\% 34$ \\
\hline $\begin{array}{l}\text { Are the historical buildings in } \\
\text { Tokat used adequately for } \\
\text { tourism? }\end{array}$ & 115 & $\% 57$ & 85 & $\% 43$ \\
\hline $\begin{array}{l}\text { Is this historical texture a problem } \\
\text { for Tokat? }\end{array}$ & 9 (problem) & $\% 5$ & $\begin{array}{l}191 \\
\text { (advantage) }\end{array}$ & $\%$ (negative) \\
\hline $\begin{array}{l}\text { Is your point of view about } \\
\text { tourists who come to Tokat } \\
\text { positive? }\end{array}$ & $\begin{array}{l}195 \\
\text { (positive) }\end{array}$ & $\% 97$ & $\% 3$ \\
\hline
\end{tabular}

The last question of the survey examined the effect of monumental buildings in portraying the city image and determined the reasons of these effects. The first historical and monumental buildings which came to the minds of the locals in terms of tourism were as follows: Taşhan, TokatKalesi (Tokat Castle), Ali Paşa Cami veHamamı (Ali Pasha Mosque and Hammam), SaatKulesi (Clock Tower), ArastalıBedesten (Bazaar), Gökmedrese (Madrasah), Yağıbasan (Çukur) Medrese (Madrasah), Mevlihane, Ulu Cami (Mosque), Yazmacılar Han1, Deveciler Hanı, HıdırlıkKöprüsü (Bridge) and Suluhan. The distribution of these responses is shown in the following table.

Table 2. The historical buildings which are city images in Tokat in terms of tourism

\begin{tabular}{|l|c|c|}
\hline & Number & Percentage (\%) \\
\hline 1-TAŞHAN (see fig-1) & 62 & 31 \\
\hline 2- SAAT KULEṠं (see fig-1) & 8 & 4 \\
\hline 3- ARASTALI BEDESTEN (see fig-1) & 7 & 3,5 \\
\hline 4- TOKAT KALESİ (see fig-1) & 37 & 18,5 \\
\hline 5- ALİ PAŞA CAMİve HAMAMI (see fig-1) & 56 & 28 \\
\hline 6- GÖKMEDRESE (see fig-1) & 12 & 6 \\
\hline 7- SULUHAN (see fig-1) & 3 & 1,5 \\
\hline 8- MEVLİHANE (see fig-1) & 1 & 0,5 \\
\hline 9- ULU CAMİ (see fig-1) & 6 & 3 \\
\hline 10- YAZMACILAR HANI (see fig-1) & 4 & 2 \\
\hline 11- DEVECİLER HANI (see fig-1) & 2 & 0,5 \\
\hline 12- YAĞIBASAN MEDRESE (see fig-1) & 1 & 1 \\
\hline 13- HIDIRLIK KÖPRÜSÜ (see fig-1) & & 0,5 \\
\hline
\end{tabular}


The participants were also asked to evaluate the historical buildings that are identified with the city of Tokat. In this context, 62 participants regarded Taşhan as a monumental building identified with the city of Tokat, 56 participants similarly considered Ali Pasha Mosque and Hammam to be associated with Tokat, and 37 participants viewed Tokat Castle to be connected to the city. It is observed in Figure 2 that the percentage distribution of survey results according to the historical buildings which are city images in Tokat in terms of tourism.

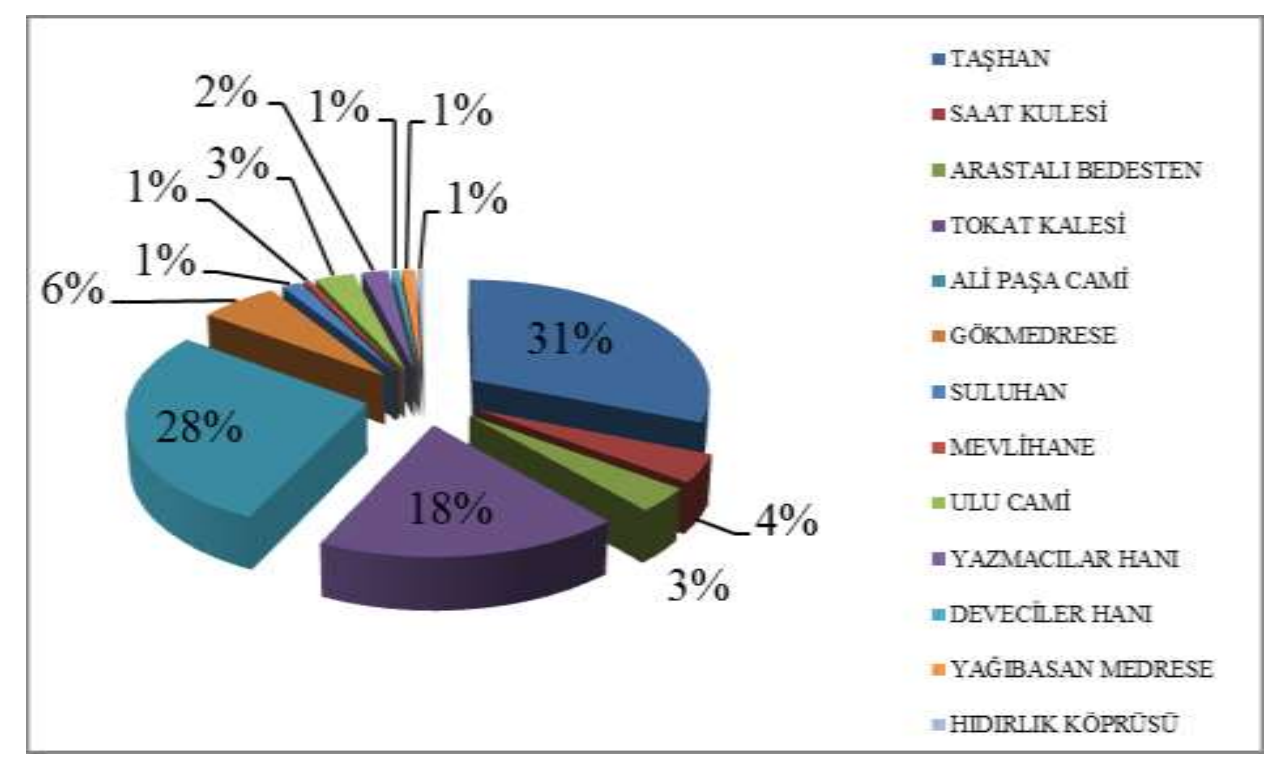

Fig. 2. The percentage distribution of survey results

According to the survey results, Taşhan, Ali Pasha Mosque and Hammam and Tokat Castle most commonly came into the minds of locals when they hear something about Tokat. When asked why the monumantal buildings in the foregoing table firstly came into their minds, the locals offered a variety of reasons. According to the survey results, $31 \%, 28 \%$, and $18 \%$ of the locals stated that the first building that came into their minds was Taşhan, Ali Pasha Mosque and Hammam, and Tokat Castle, respectively. The participants who gave Ali Pasha Mosque stated that they gave this answer because the mosque is located in the city center; it is one of the oldest mosques and has the characteristic of city image and triangulation for the city. Those who gave Taşhan as the first monumental building that came into their minds did so because Taşhan is a city image and it contributes to economy by providing tradesmen with an opportunity for their commercial activities. Most of the participants who gave the answer "Tokat Castle" stated that the Castle serves as a symbol for introducing the city and it is important for the city's history. Those who gave the answer, Gökmedrese stated that it has historical importance. The participants who gave the answer "Ulu Mosque" did so because Ulu Mosque is important for them as they pray there. Those who said "Yazmacilar Hanı" emphasized its historical importance because this Han is one of the 
oldest Hans in Tokat. The participants who answered "Suluhan" did so because this building is located in Sulu Street which is an important tourism area for the city.

\section{CONCLUSIONS}

This study examined the tourism-oriented viewpoints of the locals in Tokat on the city's history, its tourism potential and the monumental buildings as portraying the city image. To obtain objective results, a survey was conducted with the locals in Tokat, and quantitative results were found. The general aim of this study is to determine whether the tourism potential of the city is used or not (in terms of monumental buildings), whether Tokat is a tourist city or not, and the attitudes of locals towards tourism and tourists, by learning the culture tourism-oriented viewpoints of locals on monumental buildings in Tokat. This study showed that Tokat has an important tourism potential. Also, it was found that Taşhan (31\%), Ali Pasha Mosque (28\%) and Tokat Castle $(18 \%)$ were regarded as city images by the locals in terms of monumental buildings with tourism potentials and city image.

Tourism has gradually become important in the process of the transition from the concept of "single monument in the city" to the concept of "the city as a monument" (Binan 1999) which was identified at the Paris Congress in 1957. The monumental works that reflect the national identity and sense of art best, by means of the works of previous civilizations, has gradually begun to be identified with cities. It can be stated that the perspectives of the locals on tourism and tourist were in the direction of hospitality as $97 \%$ of the participants stated that their attitudes towards tourists in Tokat are positive. Despite the reconstruction plans for conservation of urban conservation sites for housing and the restriction of regional preservation board's decisions, the fact that $95 \%$ of the locals regarded the historical texture as an important tourism potential indicates the support for tourism. The fact that $57 \%$ of the locals stated that the buildings are used for the tourism draws attention in terms of the use of these buildings in Tokat for tourism. It can be concluded that there are still buildings which have a tourism potential, but are not used for tourism. Therefore, strategies should be developed to enable these buildings to be used for tourism. The question, "Is Tokat a tourist city?" was answered affirmatively by $66 \%$ of the locals. It can be stated that the reason the rest of locals did not regard Tokat as a tourist city is that they observe some inadequacies in terms of the representation of the city at national and international levels. The second important factor is transportation.

Monumental buildings are important elements which form the architectural technology of the period, the power of the civilization that has control over the region, the social lives of the nations that have lived there, and the history of the city. These elements that constitute the structure of a city enable communities to interact with each other, and therefore, they become an important element of cultural tourism. The fact that there is a lack of history in today's modern cities and their divergence from the spirit of history causes individuals to seek to visit historical cities further afield. Monumental buildings 
in the historical texture attract tourists more in terms of their introduction of the city due to their uniqueness, being a social identity element, their mass, scale, and the architectural material used.

\section{REFERENCES}

1. Binan, C. (1999). Mimari koruma alanında Venedik tüzüğ̈̈'nden günümüze düşünsel gelişimin uluslararası evrim süreci. İstanbul: YTÜ Mimarlık Fakültesi Yayınları.

2. Bujdosó, Z., Dávid, L., Tőzsér, A., Kovács, G., Major-Kathi, V., Uakhitova, G., Katona, P., Vasvári, M. (2015).Basis of heritagization and cultural tourism development. Procedia - Social and Behavioral Sciences, 188, 307-315.

3. Gunn, C. (1993). Tourism planning. New-Jersey: Taylor\&Françis Publish.

4. Dávid, L, Jancsik, A, \&Rátz, T. (2007).Turisztikaierőforrások. Budapest: BGF.

5. Dredge, D. (2004). Development, economy and culture: cultural heritage tourism planning Liangzhu China. Asia Pacific Journal of Tourism Research, 9(4), 405-422.

6. Emekli, G. (2006). Coğrafya, kültürveturizm: kültürelturizm. EgeCoğrafyaDergisi, 15, 51-59.

7. Kaufman, T.J., \& Weaver, P.A. (2006). Heritage tourism: A question of age. Asia Pacific Journal of Tourism Research, 11(2), 136-145.

8. Mathieson, A., \& Wall, G. (1982). Tourism: economic, physical and social impacts. Harlow, UK: Longman.

9. Nguyen, T.H.H., \& Cheung, C. (2014). The classification of heritage tourists: a case of Hue City Vietnam. Journal of Heritage Tourism, 9(1), 35-50.

10. Smith, A., (2007). Monumentality in 'Capital' Cities and Its Implications for Tourism Marketing. Journal of Travel \& Tourism Marketing, 22(3-4), 79-93.

11. Timothy, D. J. (2011). Cultural heritage and tourism: An introduction. Bristol: Channel View Publications.

12. Ung, A., \&Vong, T.N. (2010).Tourist experience of heritage tourism in Macau SAR China. Journal of Heritage Tourism, 5(2), 157-168.

13. Verschaffel, B. (1999). The monumental: on the meaning of a form. The Journal of Architecture, 4, 333-337. 